\title{
Fragmentations and Proton Transfer Reactions of Product Ions Formed from Mono-, Di-, and Triethanolamines
}

\author{
Sung-Seen Choi and Hun-Young So ${ }^{\dagger}$ \\ Department of Applied Chemistrv, Sejong Cniversin, Seoul 143-747, Korea \\ Korea Research Institute of Standards and Science. P.O. Box 102. Iuseong. Daejeon 305-600. Korea
}

Received Mav 13,2004

\begin{abstract}
Fragmentations and proton transfer reactions of mono-. di-. and triethanolamines were studied using FTMS. It was found that the most abundant fragment ion was $\left[\mathrm{M}-\mathrm{CH}_{2} \mathrm{OH}\right]^{+}$. The $\left[\mathrm{M}-\mathrm{CH}_{2} \mathrm{OH}-\mathrm{H}_{2} \mathrm{O}\right]^{-}$was observed in the mass spectra of diethanolamine and triethanolamine. By increasing the ion trapping time in the ICR cell. the $[\mathrm{M}+\mathrm{H}]^{-}$and $\left[\mathrm{M}+\mathrm{H}-\mathrm{H}_{2} \mathrm{O}\right]^{-}$ions were notably increased for all the samples while the $\left[\mathrm{M}+\mathrm{H}_{-}-2 \mathrm{H}_{2} \mathrm{O}\right]^{+}$was observed in the mass spectra of diethanolamine and triethanolamine. The proton transfer reactions between the fragment ions and neutral molecules occurred predominantly by increasing the ion trapping time. The rate constants for the proton transfer reactions were calculated from experimental results. The proton transfer reaction of $\mathrm{CHO}^{-}$was the fastest one. which is consistent with the heats of reaction. The rate constants for proton transfer reactions of triethanolamine were much slower than those of ethanolamine and diethanolamine because of the steric hindered stnicture of triethanolamine. The plausible stuctures of observed ions and heats of reaction for proton transfer were calculated with AMl semiempirical method.
\end{abstract}

Key Words : Proton transfer reaction, Fragmentation, FTMS. Ethanolamines. Dehydration

\section{Introduction}

Fourier transform mass spectrometer is a relatively new type of instrument, which has its origins in the omegatron ${ }^{1}$ and the ion cyclotion resonance (ICR) spectrometer. ${ }^{2}$ The transition to FTMS required developments of a trapped ion cell. first introduced to the ICR comnumity by McIver, ${ }^{3}$ and of methods to excite rapidly and detect simultaneously all the ions. The first FT mass spectrometer was demonstrated by Conisarow and Marshall. ${ }^{+}$Fourier transform mass spectrometry (FTMS) has been widely used to study gas phase chemistry. Its capability of both trapping ions and high resolution mass analysis has motivated researchers to utilize FTMS as one of the premier methods for exploring gas phase ion-molecule chenistry.

Molecular ions with specific functional group undergo typical fragmentation patterns which are used to obtain structural information. ${ }^{102}$ For exantele. the electron intpact (EI) mass spectra of alcohols and ethers show prominent ions of general fornula. $\left.\mathrm{C}_{n} \mathrm{H}_{2 n} \mathrm{O}^{-*}\right]^{10] 1}$ Ionized alcohols are fragnented and rearranged by loss of a water molecule. ${ }^{1: 13}$ Fragmentations of bifunctional molecular ions having general formula of X-R-Y have been investigated. ${ }^{1+-18}$ Blanc and coworkers ${ }^{10}$ studied the formation of ring structure by rearrangement of aliphatic diols having general formula of $\mathrm{HO}\left(\mathrm{CH}_{2}\right)_{n} \mathrm{OH}$ with $n=2-11$. Audier and coworkers ${ }^{15}$ investigated fragmentations of $\mathrm{X}\left(\mathrm{CH}_{2}\right)_{n} \mathrm{Y}^{+*}$, where $\mathrm{X}$ and $\mathrm{Y}$ $=\mathrm{NH}_{-}, \mathrm{SH}$ or $\mathrm{OH}$, and elimination reactions of $\mathrm{XH}$ from its protonated molecule. Fragmentations of molecular ions of amino alcohols. having general formula of $\mathrm{HO}-\mathrm{R}_{-} \mathrm{NH}_{2}$, were also studied by several groups. ${ }^{16-1 \S}$ Bensimon and cowork-

"Correspondence should be addressed. e-mail: sschoi ers $^{16}$ studied fragmentation of protonated ethanolamine, while Houriet and covvorkers ${ }^{17}$ studied protonation and delyydration of $\beta$-amino alcohols. Eiclumann and Brodbelt ${ }^{18}$ studied dehydration and deammoniation of protonated $\mathrm{H}_{2} \mathrm{~N}\left(\mathrm{CH}_{2}\right)_{n} \mathrm{OH}$ with $\left.n=2-6\right]$ and reported that protonation at amine site is more favorable than at hydrosyl site.

Ethanolamine ( $\left.\mathrm{HOCH}_{2} \mathrm{CH}_{2} \mathrm{NH}_{2}\right)$ has two different functional groups of hydroxyl and amine which have high proton affinities. Diethanolamine $\left(\mathrm{HN}\left(\mathrm{CH}_{2} \mathrm{CH}_{2} \mathrm{OH}\right)_{2}\right)$ and triethanolamine $\left(\mathrm{N}\left(\mathrm{CH}_{2} \mathrm{CH}_{2} \mathrm{OH}\right)_{3}\right)$ are derivatives of ethanolamine and hindered by the increased $\mathrm{CH}_{2} \mathrm{CH}_{2} \mathrm{OH}$ group. Protonations at amine and hydroxyl sites are competition reactions. In the present work, we studied variation of the formation of protonated molecule with the number of $\mathrm{CH}_{2} \mathrm{CH}_{2} \mathrm{OH}$ group. Proton transfer reactions between the fragment ions and neutral molecules were also investigated. Relations of the rate constants for proton transfer reactions with heats of reaction were investigated.

\section{Experimental Section}

All the experiments were carried out in an Extrel FTMS 2000 Fourier transform ion cyclotron resonance (FT/ICR) mass spectrometer. The instrument is equipped with two diffusion pumps attached to dual ion trapping cells aligned collinearly in a superconducting magnet of 3.1 Tesla. The cells are 2 inch cubic and a conductance limit is shared between the two cells. The nominal value of background pressure measured with nude ion gauge was lower than $1 \times$ $10^{-8}$ Torr. Samples were introduced into the cell through a leak valve or heated batch inlet depending on the desired experiment. A general pulse sequence employed to trap mass selected ions and to monitor fragments is depicted in 


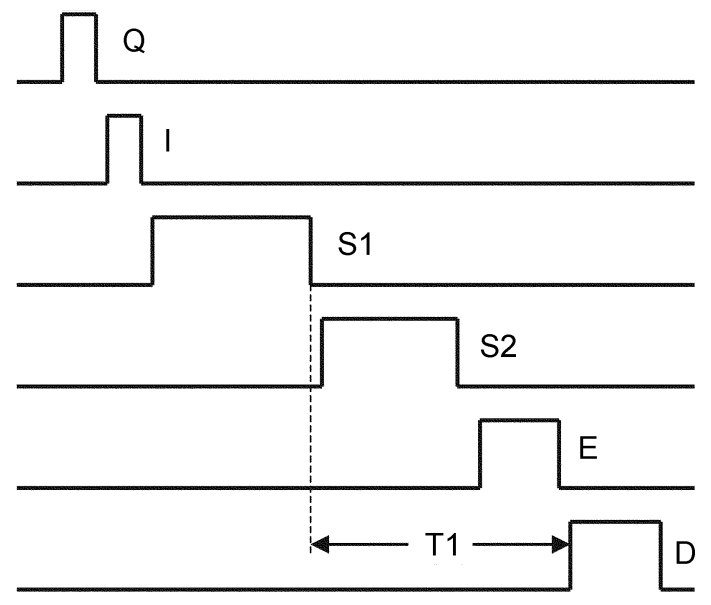

Figure 1. The pulse sequence of l' I'MS, $Q$ is the quench pulse. I is the ionization pulse by electron ionization. SI and $\mathrm{S} 2$ art the first and scoond SWIFT pulses. respectively. $E$ is the cxcitation. and D is the detection period. Tl is the decomposition time of the precursor ions in $\mathrm{SI}$.

Figure 1. After the electron ionization, first SWIFT ${ }^{21.22}$ pulse (SI) is followed to eject all fragments except the interest precursor ion. The second SWIFT pulse (S2) is performed to trap the precursor ion and primary fragment ions. The excitation pulse is varied to observe fragnentation patterns. The precursor ions in the $\mathrm{S} 1$ are decomposed into smaller ions during the $\mathrm{T} 1$. In this study, the $\mathrm{S} 2$ pulse was not applied.

Г:thanolamine, diethanolamine, and triethanolamine purchased from Aldrich $\mathrm{Co}$. were used without further purification. Heats of reaction for the fragmentations and proton transfer reactions were calculated using the heats of formations of ions, neutral molecules, and radicals. The heats of formation of neutral molecules and radicals were obtained from the literature ${ }^{2.3}$ except those of the neutral molecules of ethanolamine, diethanolanine, and triethanolamine. The heats of formation of observed ions were calculated by AMI semiempirical method..$^{24}$ Calculational results for the heats of reaction were used to elucidate the fragmentations and proton transfer reactions.

\section{Results and Discussion}

$$
\begin{array}{ccc}
\mathrm{H}_{2} \mathrm{NCH} \mathrm{CHI}_{2} \mathrm{OHI} & \mathrm{IIN}\left(\mathrm{CH}_{2}\left(\mathrm{CH} \mathrm{H}_{2} \mathrm{OH}\right)_{2}\right. & \mathrm{N}\left(\mathrm{CH} \mathrm{I}_{2}\left(\mathrm{CH}_{2} \mathrm{OHI}\right)_{3}\right. \\
\text { VIEA } & \text { DEA } & \text { TEA }
\end{array}
$$

Fragmentation of Molecular Ion. Mass spectra obtained at the short ion trapping time of 1 ms show the various fragment ions (Figure 2). The most abundant fragment ions are $\mathrm{m} / \mathrm{z}$ 30. 74, and 118 for MEA. DEA, and TEA, respectively. The $\left[\mathrm{M}-\mathrm{CH}_{2} \mathrm{OH}\right]^{+}$can be formed by a direct dissociation of $\mathrm{C}-\mathrm{C}$ bond from the molecular ion. Of the fragmentations of the molecular ion, the formation of [M$\left.\mathrm{CH}_{2} \mathrm{OH}\right]^{-}$is the most favorable one as listed lables 1-3. Heats of reaction for the fragmentations were summarized in lables 1, 2. and 3 for MEA, DEA, and TEA, respectively.

Fragment ions such as $\mathrm{CH}_{2} \mathrm{~N}^{+}, \mathrm{CHO}^{-}, \mathrm{CH}_{4} \mathrm{~N}^{-}, \mathrm{CH}_{3} \mathrm{O}^{-}$,
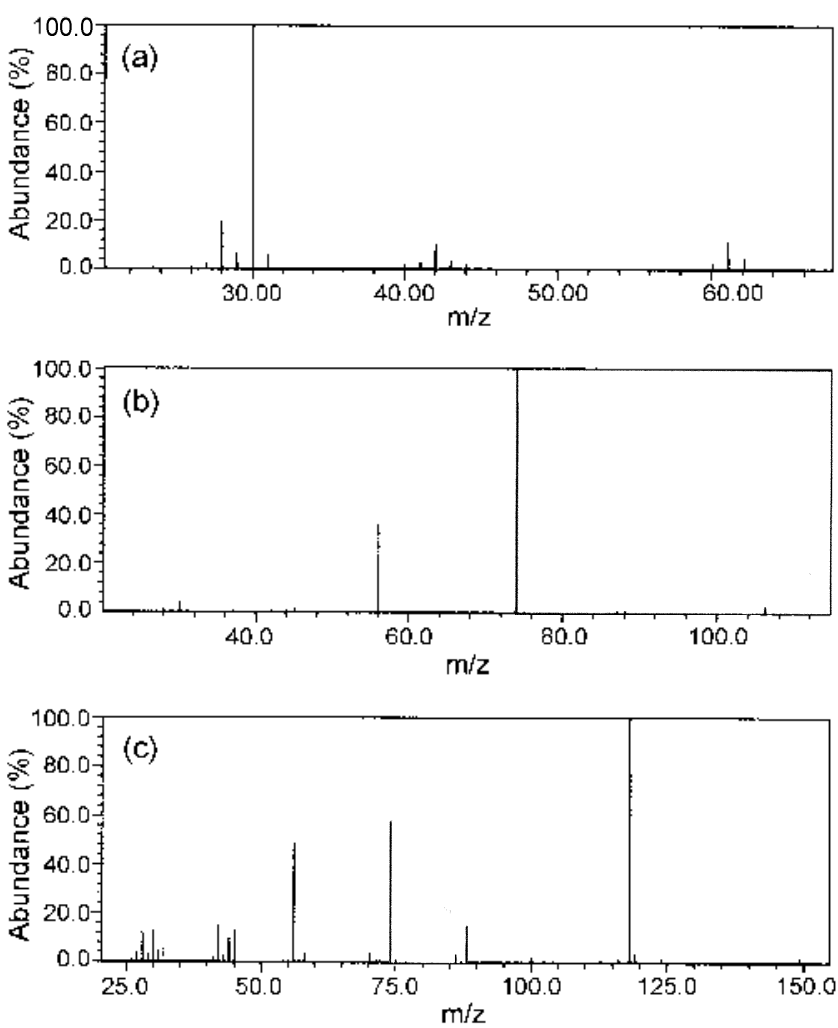

Figure 2. Flectron impact ionization mass spectra of ethanolamine (a). diethanolamine (b). and trielhanolamine (c) al the electron impact energy of $70 \mathrm{eV}$ and the ion trapping time of $1 \mathrm{~ms}$. The sample pressures are $1.9 \times 10^{-6} .2 .5 \times 10^{-6}$. and $1.2 \times 10^{-6}$ Torr for ethanolamine. diethanolamine. and triethanolamine. respectively.

$\mathrm{C}_{2} \mathrm{H}_{4} \mathrm{~N}^{+}, \mathrm{C}_{2} \mathrm{H}_{3} \mathrm{O}^{+}, \mathrm{C}_{2} \mathrm{H}_{6} \mathrm{~N}^{-}$, and $\mathrm{C}_{2} \mathrm{H}_{3} \mathrm{O}^{+}(\mathrm{m} / 7.28,29,30.31$, $42,43,44$, and 45 , respectively) are generated from all the samples of MEA, DEA, and TEA as shown in Figure 2. For MEA, the $\mathrm{CH}_{3} \mathrm{O}^{+}$and $\mathrm{CH}_{4} \mathrm{~N}^{+}$are formed by the direct dissociation of the same $\mathrm{C}-\mathrm{C}$ bond of the molecular ion. For DEA and TEA, the $\mathrm{CH}_{\hat{3}} \mathrm{O}^{+}$is also formed by direct $\mathrm{C}-\mathrm{C}$ bond dissociation of the molecular ion but the $\mathrm{CH}_{4} \mathrm{~N}^{+}$is formed by a secondary fragmentation not the direct bond dissociation of molecular ion. Relative ion intensity ratios of $\mathrm{CH}_{3} \mathrm{O}^{+} / \mathrm{CH}_{4} \mathrm{~N}^{-}$obtained from Figure 2 are MEA : DEA : TEA $=0.07: 0.17: 0.43$. The formation of $\mathrm{CH}_{3} \mathrm{O}^{-}$is increased with increasing the number of $\mathrm{CH}_{2} \mathrm{CH}_{2} \mathrm{OH}$ groups in the sample. Relative ion intensity ratios of $\mathrm{CH}_{2} \mathrm{OH}^{-}[\mathrm{M}-$ $\left.\mathrm{CH}_{2} \mathrm{OH}\right]^{+}$are MEA : DEA : TEA $=0.07: 0.01: 0.06$. This can be explained with the difference in heats of reaction for the formations of $\mathrm{CH}_{2} \mathrm{OH}^{+}$and $\left[\mathrm{M}-\mathrm{CH}_{2} \mathrm{OH}\right]^{-}$. Formations of $\left[\mathrm{M}-\mathrm{CH}_{2} \mathrm{OH}\right]^{-}$are much more favorable than those of $\mathrm{CH}_{2} \mathrm{OH}^{+}$by 135,179 , and $195 \mathrm{~kJ} / \mathrm{mol}$ for MEA, DEA, and TEA, respectively.

The $\mathrm{C}_{3} \mathrm{H}_{6} \mathrm{~N}^{-}(\mathrm{m} / 2$ 56) in the DEA mass spectrum of Figure 2(b) is a secondary fragment ion formed by loss of $\mathrm{H}_{2} \mathrm{O}$ from $\mathrm{C}_{\mathrm{i}} \mathrm{H}_{8} \mathrm{NO}^{+}(\mathrm{m} / \mathrm{z} 74)$. In the TEA mass spectrum of Figure 2(c), the $\mathrm{C}_{5} \mathrm{H}_{10} \mathrm{NO}^{-}(\mathrm{m} / \mathrm{z} 100)$ is also a secondary fragment ion formed by loss of $\mathrm{H}_{2} \mathrm{O}$ from $\mathrm{C}_{5} \mathrm{H}_{12} \mathrm{NO}_{2}{ }^{+}(\mathrm{m} / \mathrm{z} 118)$.

Fragmentation of Protonated Molecule. Protonated molecules, $[\mathrm{M}-\mathrm{H}]^{+}$, are formed by the proton transfer 
Table 1. Heats of reaction for the fragmentation of ethanolamine at $298 \mathrm{~K}$. Values in parentheses are heats of fomation in $\mathrm{k} \cdot \mathrm{T} / \mathrm{mol}$

\begin{tabular}{|c|c|}
\hline Reaction & $\Delta \mathrm{H}(\mathrm{kJ} / \mathrm{mol})$ \\
\hline $\mathrm{HOCH}_{2} \mathrm{CH}_{2} \mathrm{NH}_{2}^{+\bullet}(585) \rightarrow \mathrm{H}_{2} \mathrm{C}^{*} \mathrm{OH}^{-}(703)+\mathrm{H}_{2} \mathrm{NCH}_{2}^{*}(66)$ & 184 \\
\hline $\mathrm{HOCH}_{2} \mathrm{CH}_{2} \mathrm{NH}_{2}^{+\bullet}(585) \rightarrow \mathrm{CH}_{3} \mathrm{OH}^{+\bullet}(775)+\mathrm{H}_{2} \mathrm{C}=\mathrm{NH}(78)$ & 268 \\
\hline $\mathrm{HOCH}_{2} \mathrm{CH}_{2} \mathrm{NH}_{2}^{+\cdot}(585) \rightarrow c-\mathrm{CH}_{2} \mathrm{CH}_{2} \mathrm{NH}^{-*}(1024)+\mathrm{H}_{2} \mathrm{O}(-242)$ & 201 \\
\hline $\mathrm{HOCH}_{2} \mathrm{CH}_{2} \mathrm{NH}_{2}^{+*}(585) \rightarrow c-\mathrm{CH}_{2} \mathrm{CH}_{2} \mathrm{NH}_{2}^{-}(755)+\mathrm{HO}^{*}(252)$ & 422 \\
\hline $\mathrm{HOCH}_{2} \mathrm{CH}_{2} \mathrm{NH}_{2}^{+*}(585) \rightarrow \mathrm{H}_{2} \mathrm{C}^{+}=\mathrm{NH}_{2}^{-}(745)+\mathrm{HOCH}_{2}^{*}(-111)$ & 49 \\
\hline $\mathrm{HOCH}_{2} \mathrm{CH}_{2} \mathrm{NH}_{2}^{+\bullet}(585) \rightarrow \mathrm{CH}_{3} \mathrm{NH}_{2}^{+*}(820)+\mathrm{H}_{2} \mathrm{C}=\mathrm{O}(-109)$ & 126 \\
\hline $\mathrm{HOCH}_{2} \mathrm{CH}_{2} \mathrm{NH}_{2}^{+\bullet}(585) \rightarrow c-\mathrm{CH}_{2} \mathrm{CH}_{2} \mathrm{O}^{-\bullet}(915)^{a}+\mathrm{NH}_{3}(-46)$ & 284 \\
\hline $\mathrm{HOCH}_{2} \mathrm{CH}_{2} \mathrm{NH}_{2}^{+*}(585) \rightarrow c-\mathrm{CH}_{2} \mathrm{CH}_{2} \mathrm{OH}^{-}(691)+\mathrm{H}_{2} \mathrm{~N}^{*}(386)$ & 492 \\
\hline $\mathrm{H}_{2} \mathrm{NCH}_{2} \mathrm{CH}_{2} \mathrm{OH}_{2}^{+}(510) \rightarrow \mathrm{H}_{2} \mathrm{NCH}_{2} \mathrm{CH}_{2}^{+}(985)+\mathrm{H}_{2} \mathrm{O}(-242)$ & 233 \\
\hline $\mathrm{H}_{2} \mathrm{NCH}_{2} \mathrm{CH}_{2} \mathrm{OH}_{2}^{+}(510) \rightarrow c-\mathrm{CH}_{2} \mathrm{CH}_{2}-\mathrm{NH}_{2}^{+}(755)+\mathrm{H}_{2} \mathrm{O}(-242)$ & 3 \\
\hline $\mathrm{H}_{2} \mathrm{NCH}_{2} \mathrm{CH}_{2} \mathrm{OH}_{2}^{+}(510) \rightarrow \mathrm{H}_{2} \mathrm{C}=\mathrm{NH}_{2}^{+}(745)+\mathrm{CH}_{3} \mathrm{OH}(-202)$ & 33 \\
\hline $\mathrm{HOCH}_{2} \mathrm{CH}_{2} \mathrm{NH}_{3}^{+}(378) \rightarrow \mathrm{HOCH}_{2} \mathrm{CH}_{2}^{+}(757)+\mathrm{NH}_{3}(-46)$ & 333 \\
\hline $\mathrm{HOCH}_{2} \mathrm{CH}_{2} \mathrm{NH}_{3}^{+}(378) \rightarrow \mathrm{c}^{+} \mathrm{CH}_{2} \mathrm{CH}_{2} \mathrm{OH}^{+}(691)+\mathrm{NH}_{3}(-46)$ & 267 \\
\hline $\mathrm{HOCH}_{2} \mathrm{CH}_{2} \mathrm{NH}_{3}^{+}(378) \rightarrow \mathrm{H}_{2} \mathrm{C}=\mathrm{OH}^{+}(703)+\mathrm{CH}_{3} \mathrm{NH}_{2}(-23)$ & 302 \\
\hline
\end{tabular}

*Heats of formation for the neutral molecules and radicals were obtained from reference 23. "Datum obtained from J. Am. Chem. Soc. 1987. 109.7579.

Table 2. Heats of reaction for the fragmentation of diethanolamine at $298 \mathrm{~K}$. Values in parentheses are heats of formation in $\mathrm{kJ} / \mathrm{mol}{ }^{*}$

\begin{tabular}{|c|c|}
\hline Reaction & $\Delta \mathrm{H}(\mathrm{k} / \mathrm{mol})$ \\
\hline$\left(\mathrm{HOCH}_{2} \mathrm{CH}_{2}\right)_{2} \mathrm{NH}^{+}(320) \rightarrow \mathrm{HOCH}_{2} \mathrm{CH}_{2} \mathrm{NH}=\mathrm{CH}_{2}^{-}(492)+\mathrm{HOCH}_{2}^{*}(-111)$ & 61 \\
\hline$\left(\mathrm{HOCH}_{2} \mathrm{CH}_{2}\right)_{2} \mathrm{NH}^{+\bullet}(320) \rightarrow \mathrm{H}_{2} \mathrm{C}=\mathrm{OH}^{-}(703)+\mathrm{HOCH}_{2} \mathrm{CH}_{2} \mathrm{NHCH}_{2}^{*}(-143)$ & 240 \\
\hline$\left(\mathrm{HOCH}_{2} \mathrm{CH}_{2}\right)_{2} \mathrm{NH}^{+\bullet}(320) \rightarrow \mathrm{HOCH}_{2} \mathrm{CH}_{2} \mathrm{NHCH}_{2} \mathrm{CH}_{2}^{-}(573)+\mathrm{HO}^{*}(252)$ & 605 \\
\hline $\mathrm{HOCH}_{2} \mathrm{CH}_{2} \mathrm{NHCH}_{2} \mathrm{CH}_{2} \mathrm{OH}_{2}{ }^{+}(256) \rightarrow \mathrm{HOCH}_{2} \mathrm{CH}_{2} \mathrm{NHCH}_{2} \mathrm{CH}_{2}^{+}(573)+\mathrm{H}_{2} \mathrm{O}(-242)$ & 75 \\
\hline$\left(\mathrm{HOCH}_{2} \mathrm{CH}_{2}\right)_{2} \mathrm{NH}_{2}{ }^{+}(171) \rightarrow \mathrm{HOCH}_{2} \mathrm{CH}_{2} \mathrm{NH}_{3}^{-}(378)+c-\mathrm{CH}_{2} \mathrm{CH}_{2} \mathrm{O}(-53)$ & 154 \\
\hline$\left(\mathrm{HOCH}_{2} \mathrm{CH}_{2}\right)_{2} \mathrm{NH}_{2}^{+}(17 \mathrm{I}) \rightarrow \mathrm{HOCH}_{2} \mathrm{CH}_{2}^{+}(757)+\mathrm{H}_{2} \mathrm{NCH}_{2} \mathrm{CH}_{2} \mathrm{OH}(-202)$ & 384 \\
\hline$\left(\mathrm{HOCH}_{2} \mathrm{CH}_{2}\right)_{2} \mathrm{NH}_{2}^{+}(171) \rightarrow c-\mathrm{CH}_{2} \mathrm{CH}_{2} \mathrm{OH}^{-}(691)+\mathrm{H}_{2} \mathrm{NCH}_{2} \mathrm{CH}_{2} \mathrm{OH}(-202)$ & 318 \\
\hline $\mathrm{HOCH}_{2} \mathrm{CH}_{2} \mathrm{NH}=\mathrm{CHCH}_{3}{ }^{-}(432) \rightarrow\left(c-\mathrm{CH}_{2} \mathrm{CH}_{2} \mathrm{~N}\right)=\mathrm{CHCH}_{3}{ }^{+}(862)+\mathrm{H}_{2} \mathrm{O}(-242)$ & 188 \\
\hline $\mathrm{HOCH}_{2} \mathrm{CH}_{2} \mathrm{NH}=\mathrm{CH}_{2}{ }^{+}(492) \rightarrow\left(\mathrm{C}-\mathrm{CH}_{2} \mathrm{CH}_{2} \mathrm{~N}\right)=\mathrm{CH}_{2}^{+}(919)+\mathrm{H}_{2} \mathrm{O}(-242)$ & 185 \\
\hline
\end{tabular}

*Heats of fomation for the neutral molecules and radicals were obtained from reference 23.

reactions between fragnent ions and neutral molecules. It is well known that the protonation at anine site is more favorable than that at hydroxyl site of aninoalcohols. ${ }^{18}$ Protonated molecules with cationic sites on nitrogen are more stable than those on oxygen by 132.85 , and $79 \mathrm{~kJ} / \mathrm{mol}$ for MEA. DEA. and TEA. respectively as listed in Tables 13. The typical fragment ion formed from protonated molecule is $\left[\mathrm{M}+\mathrm{H}-\mathrm{H}_{2} \mathrm{O}\right]^{+}$generated by dehydration of $[\mathrm{M}+\mathrm{H}]^{+}$. Figure 3 shows $\left[\mathrm{M}+\mathrm{H}-\mathrm{H}_{2} \mathrm{O}\right]^{+}$of $\mathrm{n} / \mathrm{z} 44.88$, and 132 for MEA. DEA. and TEA, respectively. The ions of $\mathrm{m} / \mathrm{z}$ 44. 88 , and 132 can be also generated from the molecular ions by loss of $\mathrm{OH}$. However. the ions were detected by trace at short ion trapping time as shown in Figure 2. while they became one of the major product ions at long ion trapping time as shown in Figure 3. This inplies that the ions of $\mathrm{m} / \mathrm{z}$ 44. 88. and 132 at long ion trapping time are $\left[\mathrm{M}+\mathrm{H}-\mathrm{H}_{2} \mathrm{O}\right]^{+}$ generated from $[\mathrm{M}+\mathrm{H}]^{-}$by delydration since the intemal energy in the molecular ion is reduced by increasing the ion trapping time. Besides dehydration from the protonated MEA deammoniation can occur. The formation of $\mathrm{C}_{2} \mathrm{H}_{6} \mathrm{~N}^{-}$ $(\mathrm{n} / \mathrm{z} 44)$ by delyydration is more favorable than that of $\mathrm{C}_{2} \mathrm{H}_{3} \mathrm{O}^{+}(\mathrm{m} / \mathrm{z} 45)$ by deanmoniation from protonated MEA by above $200 \mathrm{~kJ} / \mathrm{mol}$ as listed in Table 1 .

The protonated DEA can have two structures with the protonating site. $\mathrm{HOCH}_{2} \mathrm{CH}_{2} \mathrm{HNCH}_{2} \mathrm{CH}_{2} \mathrm{OH}_{2}^{-}$and $\left(\mathrm{HOCH}_{2} \mathrm{CH}_{2}\right)_{2} \mathrm{NH}_{2}^{-}$. The $\mathrm{C}_{4} \mathrm{H}_{3} \mathrm{NO}^{-}(\mathrm{m} / \mathrm{Z} 88)$ is formed from $\mathrm{HOCH}_{2} \mathrm{CH}_{2} \mathrm{HNCH}_{2} \mathrm{CH}_{2} \mathrm{OH}_{2}^{-}$by loss of $\mathrm{H}_{2} \mathrm{O}$ while the $\mathrm{C}_{2} \mathrm{H}_{3} \mathrm{O}^{+}(\mathrm{m} / \mathrm{z} 45)$ and $\mathrm{C}_{2} \mathrm{H}_{8} \mathrm{NO}^{-}(\mathrm{m} / \mathrm{z} 62)$ are generated from $\left(\mathrm{HOCH}_{2} \mathrm{CH}_{2}\right) \mathrm{NH}_{2}^{-}$by loss of $\mathrm{HOCH}_{2} \mathrm{CH}_{2} \mathrm{NH}_{2}$ and $\mathrm{C}_{2} \mathrm{H}_{4} \mathrm{O}$ neutral molecules. respectively. The formation of $\mathrm{C}_{4} \mathrm{H}_{11} \mathrm{NO}^{-}$ is more favorable than those of $\mathrm{C}_{2} \mathrm{H}_{8} \mathrm{NO}^{+}$and $\mathrm{C}_{2} \mathrm{H}_{3} \mathrm{O}^{+}$by 79 and $309 \mathrm{~kJ} / \mathrm{mol}$. respectively. as listed in Table 2 , which is 
Table 3. Heats of reaction for the fragmentation of tricthanolanine at $298 \mathrm{~K}$. Values in parentheses are heats of formation in $\mathrm{kJ} / \mathrm{mol}^{*}$

\begin{tabular}{|c|c|}
\hline Reaction & $\Delta l l(k \cdot I / m o l)$ \\
\hline$\left(\mathrm{HOCH}_{2} \mathrm{CH}_{2}\right)_{1} \mathrm{~V}^{\prime *}(1 \mathrm{I}) \rightarrow\left(\mathrm{HOCH}_{2} \mathrm{CH}_{2}\right)_{2} \mathrm{~N}=\mathrm{CH}_{2}^{\prime}(3 / 2)+\mathrm{HOCH}_{2}^{*}(-111)$ & 85 \\
\hline$\left(\mathrm{HOCH}_{2} \mathrm{CH}_{2}\right)_{1} \mathrm{~V}^{\prime *}(1 \mathrm{I} 6) \rightarrow \mathrm{H}_{2} \mathrm{C}=\mathrm{OH}^{*}(703)-\left(\mathrm{HOCH}_{2} \mathrm{CH}_{2}\right)_{2} \mathrm{NCH}_{2}{ }^{*}(-307)$ & 280 \\
\hline$\left(\mathrm{HOCH}_{2} \mathrm{CH}_{2}\right)_{2} \mathrm{NCH}_{2} \mathrm{CH}_{2} \mathrm{OH}_{2}(58) \rightarrow\left(\mathrm{HOCH}_{2} \mathrm{CH}_{2}\right)_{2} \mathrm{NCH}_{2} \mathrm{CH}_{2}(375)+\mathrm{H}_{2} \mathrm{O}(-242)$ & 75 \\
\hline$\left(\mathrm{HOCH}_{2} \mathrm{CH}_{2}\right)_{1} \mathrm{NH}^{\prime}(-21) \rightarrow\left(\mathrm{HOCH}_{2} \mathrm{CH}_{2}\right)_{2} \mathrm{NH}_{2}(171)+c-\mathrm{CH}_{2} \mathrm{CH}_{2} \mathrm{O}(-53)$ & 139 \\
\hline$\left(\mathrm{HOCH}_{2} \mathrm{CH}_{2}\right)_{1} \mathrm{NH}^{\prime}(-21) \rightarrow \mathrm{HOCH}_{2} \mathrm{CH}_{2}{ }^{\prime}(757)+\left(\mathrm{HOCH}_{2} \mathrm{C}_{2} \mathrm{H}_{2}\right)_{2} \mathrm{NH}(-443)$ & 335 \\
\hline$\left(\mathrm{HOCH}_{2} \mathrm{CH}_{2}\right)_{1} \mathrm{NH}^{\prime}(-21) \rightarrow c^{-}-\mathrm{CH}_{2} \mathrm{CH}_{2} \mathrm{OH}^{\prime}(691)+\left(\mathrm{HOCH}_{2} \mathrm{CH}_{2}\right)_{2} \mathrm{NH}(-443)$ & 269 \\
\hline$\left(\mathrm{HOCH}_{2} \mathrm{CH}_{2}\right)_{2} \mathrm{~V}=\mathrm{CHCH}_{7}(214) \rightarrow\left(c-\mathrm{CH}_{2} \mathrm{CH}_{2} \mathrm{OCH}_{2} \mathrm{CH}_{2} \mathrm{~N}\right)=\mathrm{CHCH}_{7}(502)-\mathrm{H}_{2} \mathrm{O}(-242)$ & 46 \\
\hline$\left(\mathrm{HOCH}_{2} \mathrm{CH}_{2}\right)_{2} \mathrm{~N}=\mathrm{CH}_{2}^{\prime}(3 \mathrm{I} 2) \rightarrow\left(c-\mathrm{CH}_{2} \mathrm{CH}_{2} \mathrm{OCH}_{2} \mathrm{CH}_{2} \mathrm{~N}^{\prime}\right)=\mathrm{CH}_{2}^{\prime}(557)+\mathrm{H}_{2} \mathrm{O}(-242)$ & 3 \\
\hline
\end{tabular}

*I Ieats of lormation for the neutral molecules and radicals were obtained from reference 23.
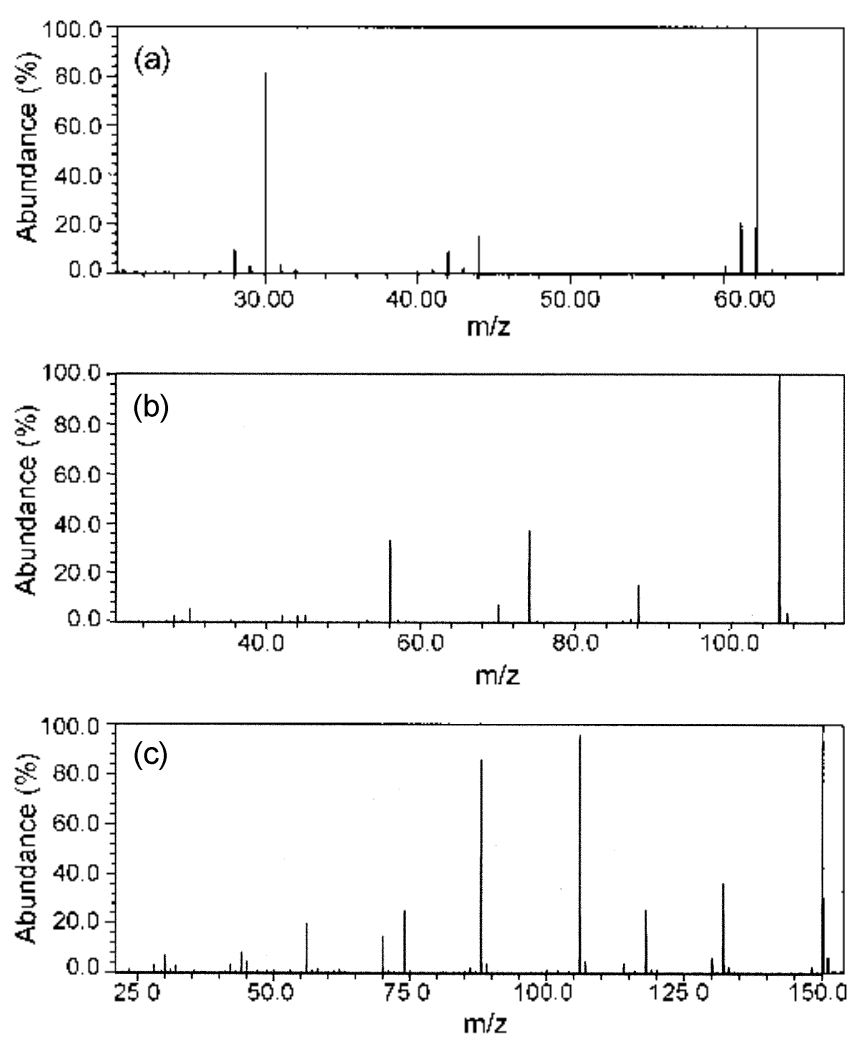

Figure 3. 1:Iectron impact ionization mass spectral ol ethanolamine (a). diethanolamine (b). and tricthanolamine (c) at the electron impact encrgy of $70 \mathrm{EV}$. The ion trapping times/sample pressures are $50 \mathrm{~ms} / 2.4 \times 10^{-6}$ Torr. $40 \mathrm{mss} / 1.5 \times 10^{-6}$ Torr. and $900 \mathrm{~ms} / 1.2 \times$ $10^{-(1}$ lor for ethanolamine, diethanolamine. and triethanolan ine. respectively.

correspondent with the experimental results as shown in rigure 3(b). The relative abundances of $\mathrm{C}_{4} \mathrm{H}_{16} \mathrm{NO}^{+}, \mathrm{C}_{2} \mathrm{H}_{8} \mathrm{NO}^{+}$, and $\mathrm{C}_{2} \mathrm{H}_{3} \mathrm{O}^{-}$are 2.64 , trace, and $14.94 \%$, respectively.

For TEA, typical fragment ions formed from the protonated molecule are $\mathrm{C}_{6} \mathrm{H}_{14} \mathrm{NO}_{2}{ }^{+}(\mathrm{m} / \mathrm{z} 132)$ and $\mathrm{C}_{4} \mathrm{H}_{12} \mathrm{NO}_{2}{ }^{-}(\mathrm{m} / \mathrm{z}$ 106). The $\mathrm{C}_{6} \mathrm{H}_{1+} \mathrm{NO}_{2}{ }^{+}$is generated from $\left(\mathrm{HOCH}_{2} \mathrm{CH}_{2}\right)_{2}-$ $\mathrm{NCH}_{2} \mathrm{CH}_{2} \mathrm{OH}_{2}^{-}$by loss of $\mathrm{H}_{2} \mathrm{O}$ while the $\mathrm{C}_{4} \mathrm{H}_{12} \mathrm{NO}_{2}^{-}$is

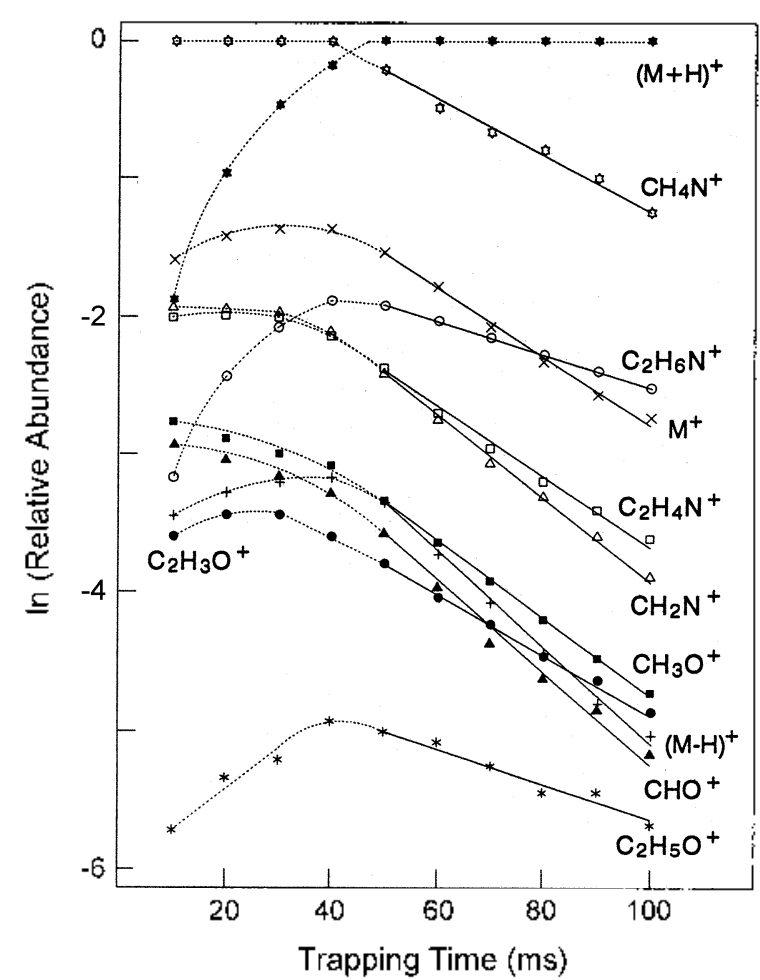

rigure 4. liemporal variation of the ion abundance for the fragmentation of ethanolamine at $70 \mathrm{cV}$ of the electron impact energy and $2.4 \times 10^{-6}$ of the sample pressure. All lragment ions are significantly decreases al $50 \mathrm{~ms}$ of the ion trapping time.

formed from $\left(\mathrm{HOCH}_{2} \mathrm{CH}_{2}\right)_{3} \mathrm{NH}^{+}$by loss of $\mathrm{C}_{2} \mathrm{H}_{4} \mathrm{O}$ neutral molecule as demonstrated in Table 3 . The $\mathrm{C}_{4} \mathrm{H}_{12} \mathrm{NO}_{2}{ }^{+}$is a protonated DEA. Thus, fragment ions formed from the protonated DEA can be also generated from the protonated TEA. The $\mathrm{C}_{4} \mathrm{H}_{10} \mathrm{NO}^{+}, \mathrm{C}_{2} \mathrm{H}_{6} \mathrm{~N}^{-}$, and $\mathrm{C}_{2} \mathrm{H}_{5} \mathrm{O}^{-}$are also observed in the mass spectra of TEA as shown in Figure 3(c).

Proton Transfer Reactions between Fragment lons and Neutral Molecules. In the short ion trapping time of $1 \mathrm{~ms}$. the $\left[\mathrm{M}-\mathrm{CH}_{2} \mathrm{OH}\right]^{+}$is the most abundant ion in the mass spectra as shown in Figure 2. By increasing the ion trapping 


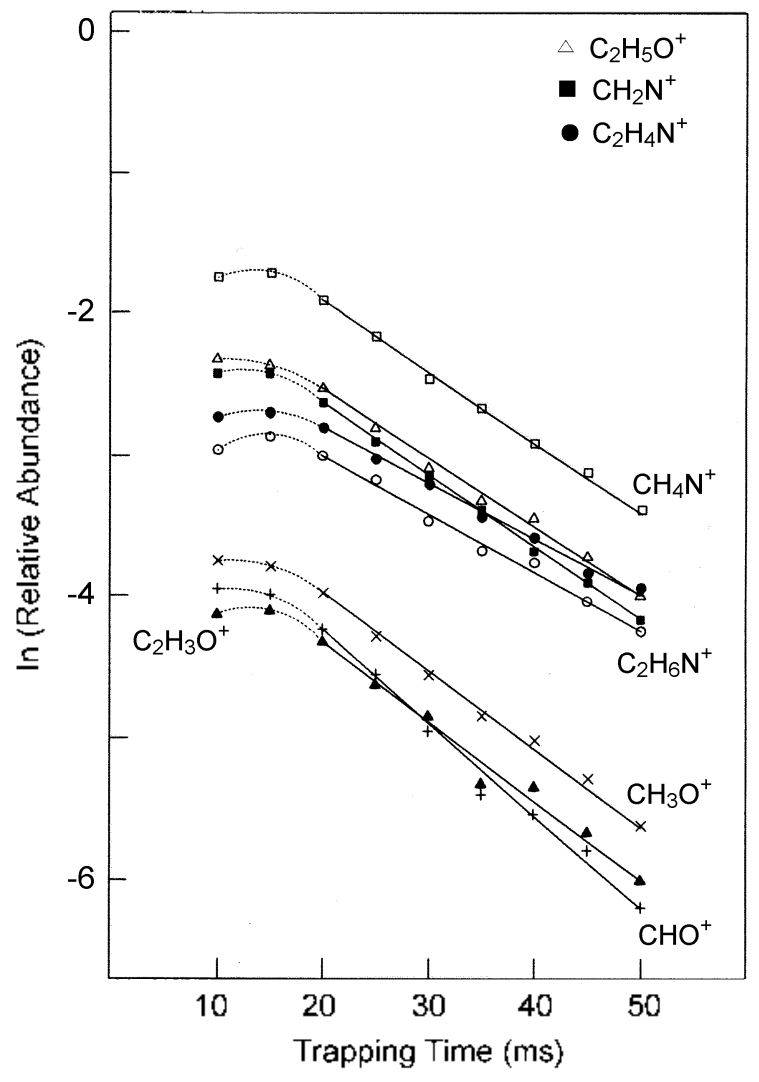

Figure 5. Temporal vartation of the $C_{1}$ and $C_{2}$ ion abundante for the fragmentation of diethanolamine at $70 \mathrm{cV}$ of the slectron impact energy and $1.5 \times 10^{-6}$ of the sample pressure. All liragment ions are significandly decreases at 20 ms of the ion trapping lime.

time, proton transfer reactions between fragment ions and neutral molecules occur. In the long ion trapping time of 50 $\mathrm{ms}$, the protonated molecules are the most abundant ion in the mass spectra as shown in Figure 3.

By increasing the ion trapping time, the internal energy with product ions are reduced and it is hard to occur further dissociations of the product ion. The ion-molecule reactions, especially proton transfer reactions, occur during ions are trapped in the ICR cell. We investigated the proton transfer reactions between product ions and neutrals depending on the ion trapping time. 'The experimental results for proton transfer reactions are summarized in Figures 4-8.

rigure 4 is a temporal variation of the ion abundances for fragment jons of MEA. which shows that the relative ion abundances of all fragments are reduced after $50 \mathrm{~ms}$ of the ion trapping time. The ion trapping time is $50 \mathrm{~ms}$ when the $[\mathrm{M}+\mathrm{H}]^{-}$becomes the most abundant ion. Figure 5 is a temporal variation of the ion abundances for fragment ions of $\mathrm{C}_{1}$ and $\mathrm{C}_{2}$ species of DEA, which shows that the relative ion abundances of all fragments are reduced after $20 \mathrm{~ms}$ of the ion trapping time. Fragment ions of $C_{3}$ and $C_{4}$ species are also reduced after $20 \mathrm{~ms}$ of the ion trapping time as shown in rigure 6. The ion trapping time is $20 \mathrm{~ms}$ when the $[\mathrm{M}+\mathrm{H}]^{+}$ becomes the most abundant ion. For TEA, as similar to DEA, after the ion trapping time of $900 \mathrm{~ms}$ the relative ion abundances of all fragment ions are reduced while the

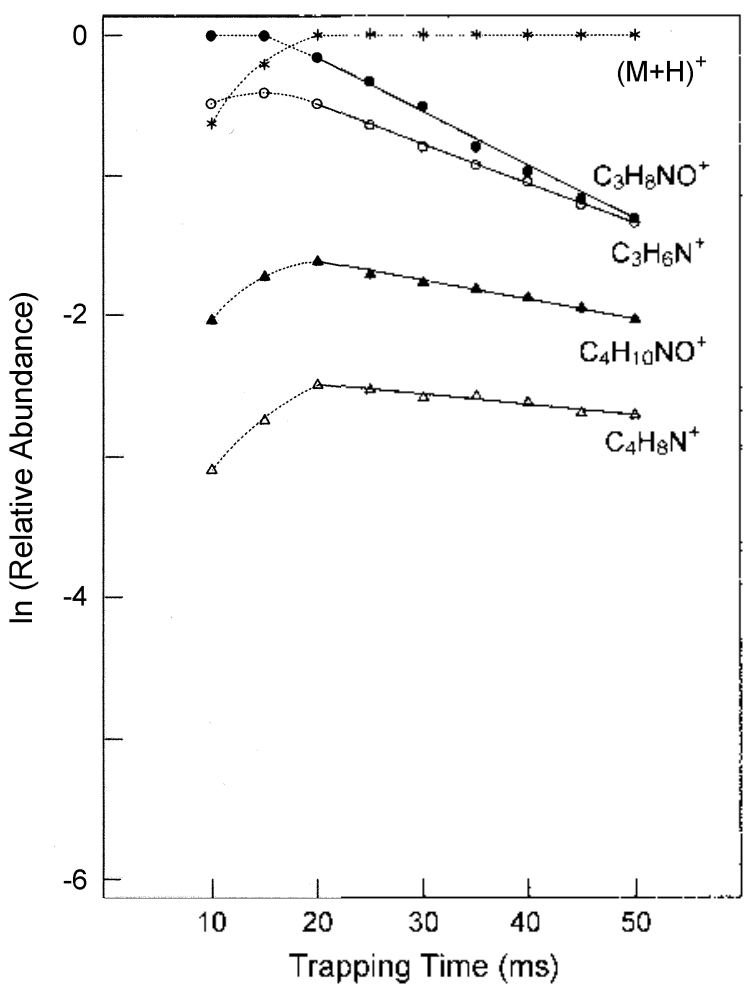

Figure 6. Temporal varialion of the $C_{3}$ and $C_{+}$ion abundance for the fragmentation of diethanolamine at $70 \mathrm{eV}$ of the electron impact energy and $1.5 \times 10^{-5}$ of the sample pressure. All fragment ions are significantly decreases at $20 \mathrm{~ms}$ of the ion trapping time.

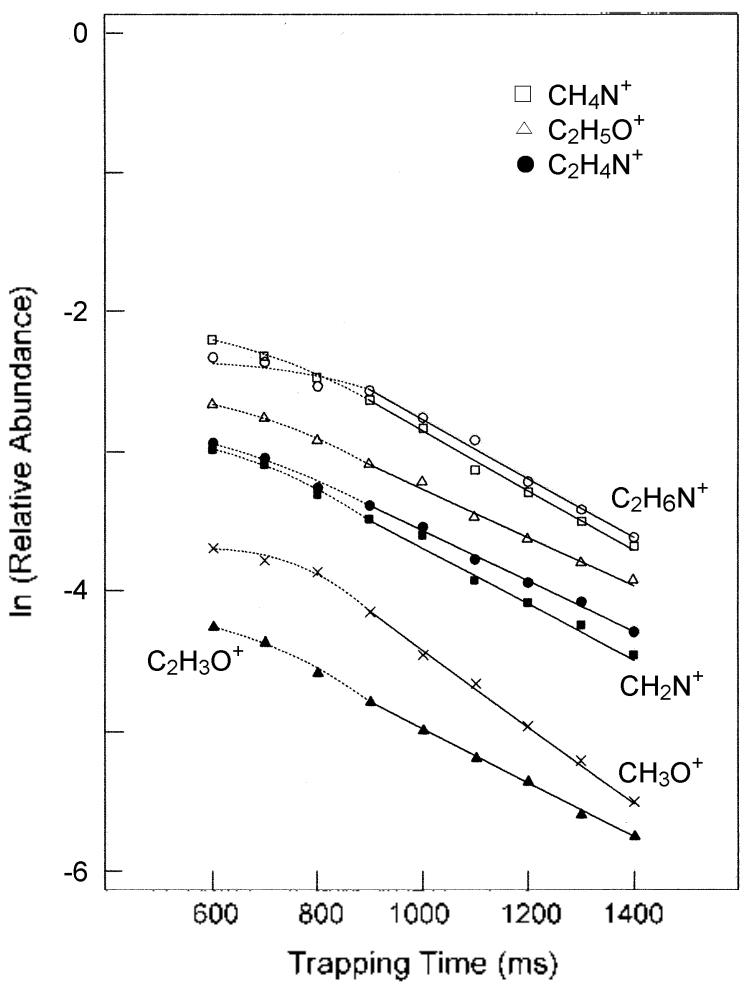

Figure 7. Temporal variation of the $C_{1}$ and $C_{2}$ ion abundance for the fragmentation of tijethanolamine at $70 \mathrm{eV}$ of the electron impact energy and $1.2 \times 10^{-6}$ of the sample pressure. $A 11$ fragment ions are significantly decreases at $700 \mathrm{~ms}$ of the ion trapping time. 


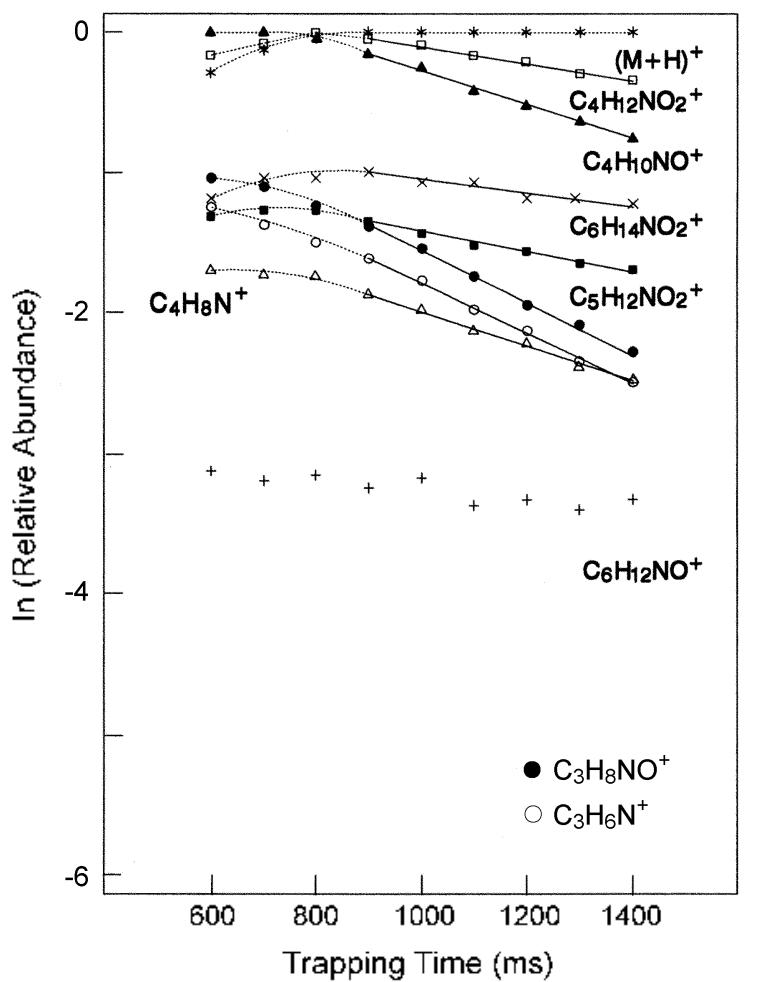

Figure 8. Temporal variation of the $\mathrm{C}_{3} \mathrm{C}_{8}$ ion abundanes tor the fragmentation of tiiethanolamine at $70 \mathrm{eV}$ of the electron impact energy and $1.2 \times 10^{-6}$ of the sample pressure. All liagment ions are significantly decreases at $700 \mathrm{~ms}$ of the ion trapping time.

$[\mathrm{M}+\mathrm{H}]^{-}$become the most abundant ion as shown in Figures 7 and 8 .

Heats of reaction for the proton transfer reactions of $C_{1}$ and $\mathrm{C}_{2}$ species are listed in Table 4 . All of the proton transfer reactions except for $\mathrm{C}_{2} \mathrm{H}_{6} \mathrm{~N}^{+}$of TEA are exothermic as shown in Table 4. Rate constants are calculated for the ion trapping times of $50-100,20-50$, and $900-1400 \mathrm{~ms}$ for MEA, DEA, and TEA, respectively, as shown in Figures 48. Rate constants obtained from the experimental results are
Table 5. Rate constants for the proton tansfer reactionts

\begin{tabular}{|c|c|c|c|}
\hline \multirow{2}{*}{$\begin{array}{l}\text { Fragment } \\
\text { ion }\end{array}$} & \multicolumn{3}{|c|}{$k\left(\times 10^{-10} \mathrm{~cm}^{1} / \mathrm{molecule} \mathrm{s}\right)$} \\
\hline & $\mathrm{HOCH}_{2} \mathrm{CH}_{2} \mathrm{NH}_{2}$ & $\left(\mathrm{HOCH} \mathrm{CH}_{2} \mathrm{CH}_{2}\right)_{2} \mathrm{NH}$ & $\left(\mathrm{HOCH}_{2} \mathrm{CH}_{2}\right)_{i} \mathrm{~N}$ \\
\hline $\mathrm{CII}_{2} \mathrm{~N}^{+}$ & 3.84 & 5.56 & 0.52 \\
\hline $\mathrm{Cll}_{4} \mathrm{~N}^{+}$ & 2.70 & 5.00 & 0.57 \\
\hline $\mathrm{C}_{2} \mathrm{Il}_{4} \mathrm{~N}^{+}$ & 3.43 & 4.17 & 0.50 \\
\hline $\mathrm{C}_{2} \mathrm{Il}_{0} \mathrm{~N}^{+}$ & 1.56 & 4.26 & 0.56 \\
\hline $\mathrm{CllO}^{+}$ & 4.26 & 6.67 & $1.15^{\prime \prime}$ \\
\hline $\mathrm{Cll}_{3} \mathrm{O}^{+}$ & 3.53 & 5.63 & 0.71 \\
\hline $\mathrm{C}_{2} \mathrm{Il}_{3} \mathrm{O}^{+}$ & 2.91 & 5.83 & 0.51 \\
\hline $\mathrm{C}_{2} \mathrm{Il}_{5} \mathrm{O}^{+}$ & 1.66 & 4.17 & 0.46 \\
\hline $\mathrm{C}_{3} \mathrm{II}_{0} \mathrm{~N}^{+}$ & & 2.87 & 0.44 \\
\hline $\mathrm{C}_{+} \mathrm{I}_{\mathrm{B}} \mathrm{N}^{-+}$ & & 0.83 & 0.29 \\
\hline $\mathrm{C}_{3} \mathrm{H}_{\mathrm{B}} \mathrm{NO}^{-}$ & & 3.87 & 0.48 \\
\hline $\mathrm{C}_{4} \mathrm{Il}_{10} \mathrm{NO}^{-}$ & & 1.30 & 0.31 \\
\hline $\mathrm{C}_{4} \mathrm{I}_{12} \mathrm{NO}_{2}^{-}$ & & & 0.14 \\
\hline $\mathrm{C}_{0} \mathrm{Il}_{12} \mathrm{NO}^{-}$ & & & of \\
\hline $\mathrm{C}_{5} \mathrm{II}_{12} \mathrm{NO}_{2}^{-}$ & & & 0.21 \\
\hline $\mathrm{C}_{0} \mathrm{Il}_{1+} \mathrm{NO}_{2}^{-}$ & & & 0.14 \\
\hline
\end{tabular}

"Its value obtained from the ion trapping time within 200 ms. It was hard to determine the rate constant of $\mathrm{C}_{6} \mathrm{H}_{12} \mathrm{NO}^{+}$from $\mathrm{F}$ igrure 8 .

listed in Table 5. Since, for TEA, the $\mathrm{CHO}^{+}$is not observed after $300 \mathrm{~ms}$ of the ion trapping time, the rate constant for $\mathrm{CHO}^{+}$of TEA is determined for the ion trapping time within $200 \mathrm{~ms}$. Among the proton transfer reactions, the fastest one is the reaction of $\mathrm{CHO}^{-}$.

The numbers of proton-accepting site (sum of nitrogen and oxygen atoms) are 2, 3, and 4 for MEA, DEA, and TEA, respectively. The rate constant for proton transfer reaction of DEA with three proton-accepting sites is faster than that of MEA with two proton-accepting sites. However, the rate constant of TEA with four proton-accepting sites is much slower than those of MEA and DEA. This can be

Table 4. I leats of reaction for the proton transfer reactions al $298 \mathrm{~K}$. Values in parentheses are heals of formation in kJ/mol. Protonated molecules are used one with the cationic site on nitrogen atom

\begin{tabular}{|c|c|c|c|c|}
\hline \multirow{2}{*}{ Fragment ion $\left(\Delta \mathrm{H}_{p}\right)$} & \multirow{2}{*}{ Neutral molecule ${ }^{a}\left(\Delta \mathrm{H}_{i}\right)$} & \multicolumn{3}{|c|}{$\Delta l \mathrm{l}(\mathrm{kJ} / \mathrm{m}) \mathrm{l})$} \\
\hline & & $\mathrm{IIOCH_{2 }}\left(\mathrm{Cl}_{2} \mathrm{NH}_{2}\right.$ & $\left(\mathrm{H} O \mathrm{COH}\left(\mathrm{CH}_{2}\right)_{2} \mathrm{NII}\right.$ & $\left(\mathrm{IIOC} \mathrm{I}_{2}\left(\mathrm{CH}_{2}\right)_{3} \mathrm{~N}\right.$ \\
\hline$t-\mathrm{CH}_{2} \mathrm{CH}_{2} \cdot \mathrm{NH}_{2}{ }^{\prime}(755)$ & $\left(-\mathrm{CH}_{2} \mathrm{CH}_{2} \mathrm{NH}(\mathrm{I} 27)\right.$ & -48 & -14 & 2 \\
\hline $\mathrm{CH}_{3} \mathrm{CH}=\mathrm{NH}_{2}{ }^{\prime}(665)$ & $\mathrm{CH}_{3} \mathrm{CH}=\mathrm{NH}(8)$ & -77 & -43 & -27 \\
\hline $\mathrm{C} H ; \mathrm{C}^{\prime} \equiv \mathrm{NH}^{\prime}(835)$ & $\mathrm{CH}_{3} \mathrm{C} \equiv \mathrm{N}(74)$ & -181 & -147 & -131 \\
\hline $\mathrm{H}_{2} \mathrm{C}^{\prime}=\mathrm{NH}_{2}{ }^{\prime}(745)$ & $\mathrm{H}_{2} \mathrm{C}=\mathrm{NH}(78)$ & -87 & -53 & -37 \\
\hline$H C^{\prime} \equiv . N H^{\prime}(955)$ & $H C \equiv N(135)$ & -240 & -206 & -190 \\
\hline$\left(-\mathrm{CH}_{2} \mathrm{CH}_{2} \mathrm{OH}^{\prime}(691)\right.$ & $c-\mathrm{CH}_{2} \mathrm{CH}_{2} \mathrm{O}(-53)$ & -164 & -130 & -114 \\
\hline $\mathrm{CH}_{3} \mathrm{CH}=\mathrm{OH}^{\prime}(583)$ & $\mathrm{CH}_{3} \mathrm{CH}=\mathrm{O}(-166)$ & -169 & -135 & -119 \\
\hline $\mathrm{C}^{\prime} \mathrm{C}_{3} \equiv \mathrm{O}^{\prime}(657)$ & $\mathrm{H}_{2} \mathrm{C}=\mathrm{CO}(-48)$ & -125 & -91 & -75 \\
\hline $\mathrm{H}_{2} \mathrm{C}=0 \mathrm{OH}^{\prime}(703)$ & $\mathrm{H}_{2} \mathrm{C}=\mathrm{O}(-\mathrm{I} 09)$ & -232 & -198 & -182 \\
\hline$H C=O^{\prime}(828)$ & $C O(-111)$ & -359 & -325 & -309 \\
\hline
\end{tabular}

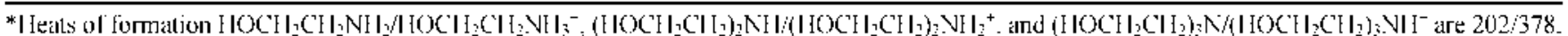
$-443 / 171$, and $65 \mathrm{I} /-21 \mathrm{~km} / \mathrm{imol}$, respectively. "Heats of formation for the neutral molecules were obtained itom reference 23. 
explained with the type of protonated TEA. TEA has two protonated molecules of $\left(\mathrm{HOCH}_{2} \mathrm{CH}_{2}\right)_{3} \mathrm{NH}^{-}\left(\Delta \mathrm{H}_{\mathrm{f}}=-21 \mathrm{l} \mathrm{kJ} /\right.$ mol) and $\left(\mathrm{HOCH}_{2} \mathrm{CH}_{2}\right)_{2} \mathrm{NCH}_{2} \mathrm{CH}_{2} \mathrm{OH}_{2}^{+}\left(\Delta \mathrm{H}_{\mathrm{f}}=58 \mathrm{~kJ} / \mathrm{mol}\right)$. The protonated molecule of TEA with a cationic site on oxygen is less stable than that on nitrogen by $79 \mathrm{~kJ} / \mathrm{mol}$. Since the nitrogen atom of TEA is hindered by three $\mathrm{CH}_{2} \mathrm{CH}_{2} \mathrm{OH}$ groups. formation of $\left(\mathrm{HOCH}_{2} \mathrm{CH}_{2}\right)_{3} \mathrm{NH}^{+}$by the proton transfer reactions will be prevented by the $\mathrm{CH}_{2} \mathrm{CH}_{2} \mathrm{OH}$ groups. Because of these reasons, the rate constant for proton transfer of TEA is much slower than those of MEA and DEA although TEA has more protonaccept sites than MEA and DEA

\section{Conclusion}

The most abundant fragment ion was $\left[\mathrm{M}-\mathrm{CH}_{2} \mathrm{OH}\right]^{+}$of the fragment ions of ethanolamine. dithanolamine, and triethanolamine. For diethanolamine and triethanolamine. the $\left[\mathrm{M}-\mathrm{CH}_{2} \mathrm{OH}-\mathrm{H}_{2} \mathrm{O}\right]^{+}$was observed. The $[\mathrm{M}+\mathrm{H}]^{+}$and $[\mathrm{M}+\mathrm{H}-$ $\left.\mathrm{H}_{2} \mathrm{O}\right]^{-}$increased notably with increase of the ion trapping time. The proton transfer reactions between the fragment ions and neutral molecules occurred at long ion trapping time. The proton transfer reaction of $\mathrm{CHO}^{+}$was the fastest. The rate constant for proton transfer reaction of triethanolamine was much slower than those for ethanolamine and diethanolamine due to the steric hindered structure.

\section{References}

1. Sommer, H.: Thomas. H. A.: Hipple. J. A. Phys. Rev 1949. 76. 1877 .

2. Wobschall. D. Re?. Sci. Instrim. 1965. 36. 466.
3. McIver. R. T. Rev Sci. Instrum. 1970. 11. 555.

4. Comisarow: M. B.: Marshall. A. G. Chem. Phus. Lett. 1974. 25. 582 .

5. Dearden. D. A.; Liang. Y.; Nicoll. J. B; Kellersberger, K. A. J. Mass Sipectront 2001. $36,989$.

6. Nibbering. N. M. M. Acc. Chem. Res. 1990. 23. 279.

7. Buchanant. M. V.: Hettich. R. L. Anal. Chem. 1993. 65. 245A.

8. Marshall. A. G. Acc. Chem. Res. 1985. 18.316.

9. Gross. M. L.: Rempel. D. L. Science 1984, 226. 261

10. Lossing. F. P. J. Am. Chent. Soc. 1977, 99,7526.

11. Harrison, A. G.: Keves. B. G. J. An Chent Scc. 1968, 90. 5046.

12. Liou. C.-C.: Eichmant1. E. S.: Brodbelt. J. S. Org Mass Spectrom. 1992. 27. 1098 .

13. Ahmed. M. S.: Hudson, C. E.: Giam, C. S.; McAdoo. D. J. Org. Mass Spectron. 1991. 26, 1089.

14. Blane. P. A.: Gulacar, F. O.: Buch. A. Org Mass Spectront 1978. 13. 135.

15. Audier. H. E.: Milliet. A.: Perret. C.: Tabet. T. C.: Varent1e. P. Org. Mass Spectrom. 1978.13.315.

16. Bensimon. M:- Rapin. J.: Houriet, R. Spectros. Int. J. 1984. 3. 145.

17. Houriet. R.: Refenacht. H; Stahl, D.: Tichy. M.: Longevialle, P. Org. Mass Spectrom. 1985. 20. 300 .

18. Eichman. E. S.: Brodbelt. J. S. Org. Mass Spectrom 1993. 28. 665 .

19. Nam. J. J.; Lee. S. H. Bull. Korean Chem. Soc. 2002. 23. 1097.

20. El-Deen. I. M; El-Fattah. M. E. Bull. Korem Chen. Soc. 2003. 24.559.

21. Marshall. A. G.: Wang. T.-C. L.: Ricca. T. L. J. Am. Chem. Soc. 1985. 107.7893.

22. Zimmerman. J. A.: Creasy, W. R. J. Chent. Phss 1992. 96, 1942.

23. Lias. S. G.: Liebman, J. F, Levin, R. D. J. Phys Chem. Ref. Data 1984. 13,695

24. Eichmanl. E. S.: Brodbelt. T. S. J. Am. Soc. Mass Spectom. 1993. 4. 230 . 